\title{
INFLUENCE OF TIE BEAMS ON THE SHALLOW ISOLATED ECCENTRIC FOOTING SYSTEM
}

\author{
Almasmoum A.A. \\ Associate Prof. , Engineering \& Islamic College, Civil Eng. Department, \\ Umm Al Qura University, Makkah AL Mukarramah, Kingdom Of \\ Saudi Arabia.
}

(Received January 20, 2009 Accepted February 3, 2009)

\begin{abstract}
Tie-beams of footing are widely used to connect all isolated footings including eccentric footings. In the case of eccentric footing the tie beam is called strap beam. Numerical parametric finite element method has been applied to study the considered tie beams - footings system. The influence of strap beams connected with eccentric footing and tie beams connected with centric interior footing in the contact pressure, the percentage of column loads transmitted by tie beams, the percentage ratio of vertical displacement to length of tie beam at different points under footings and tie beams and maximum percentage ratio of differential displacement to length of tie beam are analyzed. As well as the effect of tie beam stiffness, allowable bearing capacity of soil and tie beam position (in the level of footing and above the surface of footing) in the mentioned behavior of tie beams-footings are studied.
\end{abstract}

\section{INTRODUCTION}

It is well known, when the external column is very near to the property line, the footing cannot be spread beyond on the property line, so, the footing must be connected by strap beam to the nearest interior footing.The strap beams serve to transfer the column loads on to the soil with uniform soil pressure under both footings. The traditional solution of strap beam assumes it rigid to control rotation of eccentric footing and the strap beam should be out of contact with soil. The constructing of strap beams needs large quantities of concrete and reinforcement. This method has ignored the influence of contact pressure under strap beam, flexibility of strap beam and effect of superstructure. The economic design may be obtained if the mentioned factors are taken into consideration. Tie beams resting directly on soil are widely used to connect shallow footings, including strap or eccentric footing, in two directions. It is believed that these beams help in reducing differential settlement. Practically, strap beam for eccentric footings are used with other tie beams for centric footings in foundation, but it is designed separately. However, this system of beams and footings is considered as rigid and must be treated as one entity, where the tie beams play important role for redistribution of column loads between footings through it.

Many attempts have been made to study the behavior of tie beams in the shallow isolated footing system. The slab action of footing is taken into consideration to analyze the beam- footing system $[1,2]$. Behavior of strap footings with tie beams resting on soil was studied using finite difference technique [5]. The foundation of 
isolated footing connected with tie beams can be considered as one unit and the column loads may be distributed between cross beams in two directions [3, 6, 7, 8, 9, and 10].

The objective of this paper is to study the influence of strap beam or tie beam stiffness and allowable bearing capacity of soil in contact pressure, the percentage of column loads transmitted by tie beams, the percentage ratio of vertical displacement to length of tie beam (at edge of eccentric footing, middle of strap beam, centre of interior footing and middle of second tie beam) and the maximum percentage ratio of differential displacement to length of tie beam. Role of tie beam position in the same level of footing and above the surface of footing is presented. The present study was carried out by using a finite element commercial package [4].

\section{CASE OF STUDY}

In this research, the case of study of shallow isolated eccentric and centric footing connected with tie beams in the same level of footing and above the surface of footing is shown in Fig.(1). A numerical parametric finite element technique [4] is carried out in the case of study .It has been chosen the different allowable bearing capacity of soil of $50,100,125$ and $200 \mathrm{KN} / \mathrm{m} 2$. The various stiffness of tie beams are obtained by taken beam thickness $0.75,1.00,1.25$ and $1.50 \mathrm{~m}$. The column loads were changed according to different values of allowable bearing capacity of soil by considering the applied pressure equal to allowable bearing capacity to keeping the same foundation area for all cases of study. In the present study, the tie beam level is taken into consideration, so that the solid element is used to represent footings and tie beams. The columns are also represented by solid element for the sake of compatibility and good connection between columns, tie beams and footings. The solid elements used are an eight-node hexahedron isoperimetric element with three translational degrees of freedom per node. Winkler model is used to represent the soil with two nodes spring element and one degree of freedom per node (axial translation). The soil behavior is assumed to be linear. The top node of the spring element is attached to the nodes of the bottom surface of the footings and the tie beams, while the bottom node of spring element is totally fixed.

The spring stiffness is calculated by the following equation:

Where:

$$
\mathrm{Ks}=\mathrm{k} * \mathrm{~A}
$$

Ks $=$ Spring stiffness in units force / length .

$\mathrm{K}=$ Modulus of subgrade reaction in unit force/ cubic length.

$\mathrm{A}=$ Area carried by spring in units square length.

The modulus of subgrade reaction was calculated based on the allowable bearing of soils according to Bowel's (1988) equation:

Where:

$$
\mathrm{K}=40 \mathrm{~F} * \mathrm{q}_{\mathrm{a}}
$$

$\mathrm{K}=$ Modulus of subgrade reaction $\left(\mathrm{KN} / \mathrm{m}^{3}\right)$.

$\mathrm{F}=$ Factor of safety.

$\mathrm{q}_{\mathrm{a}}=$ Allowable bearing capacity $\left(\mathrm{KN} / \mathrm{m}^{2}\right)$. 

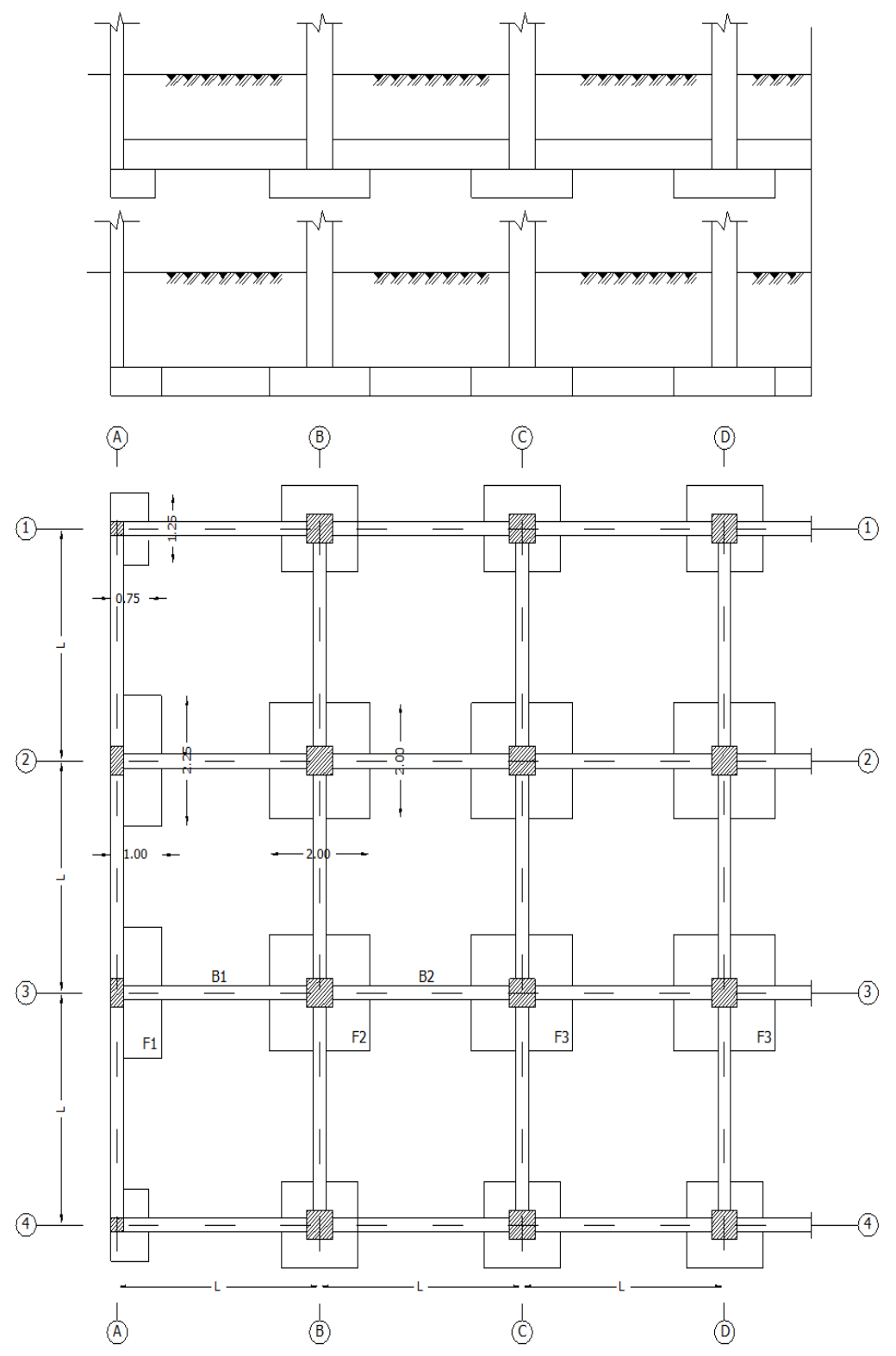

Fig. 1 Footing beam system

\section{NUMERICAL STUDY RESULTS}

The influence of stiffness of tie beam and allowable bearing capacity on the contact pressure, the percentage of column loads transmitted by tie beams, the percentage ratio of vertical displacement to length of tie beam at edge of eccentric footing (F1), middle of strap beam (B1), centre of interior footing (F2) and at middle of second tie beam (B2) and maximum percentage ratio of differential displacement to length of tie beam 
are presented. Moreover, the influence of tie beam position; in the same level of footing and above the surface of footing in the behavior of eccentric footing is studied.

The relationship between thickness of tie beam and contact pressure at different values of bearing capacity at middle of strap beam B1, centre of interior footing F2 and at middle of tie beam B2 are shown in Figs.( 2-1 to 2-3 ). Generally, these figures show the contact pressure increases as the thickness of tie beam and the bearing capacity of soil increase.

It is shown from Fig. (3) that the contact pressure at middle of strap beam (B1) is smaller than that at footing (F2) and tie beam (B2) at low thickness of strap and tie beam, but at height its thickness the contact pressure is nearly closed together.

The effect of tie beam thickness on the percentage of column loads transmitted by tie beams is shown in Fig. (4). Generally it is clear cleared from this figure that the percentage of column loads transmitted by strap and tie beams increases with increasing the thickness of strap and tie beams, but it decreases as the allowable bearing capacity of soil increases. Also, it is noticed that at height stiffness of tie beams, the decreasing of load transmitted percent by tie beams with increasing the bearing capacity of soil is smaller than that at law stiffness of tie beams.

The effect of bearing capacity and thickness of tie beams on the percentage ratio of vertical displacement to length of tie beam $(\mathrm{S} / \mathrm{L} \%)$ at the edge of eccentric footing(F1), middle of strap beam (B1), centre of interior footings (F2), middle of second tie beam (B2) and at the centre of interior footings (F3) are shown in Figs.(5-1 to 5-5).Generally, it is noticed from these figures that ( $\mathrm{S} / \mathrm{L} \%)$ increases as the bearing capacity of soil increases and the thickness of tie beams decrease, except at the middle of strap beam (B1), it decreases with increasing the bearing capacity of soil and with decreasing the thickness of tie beams.

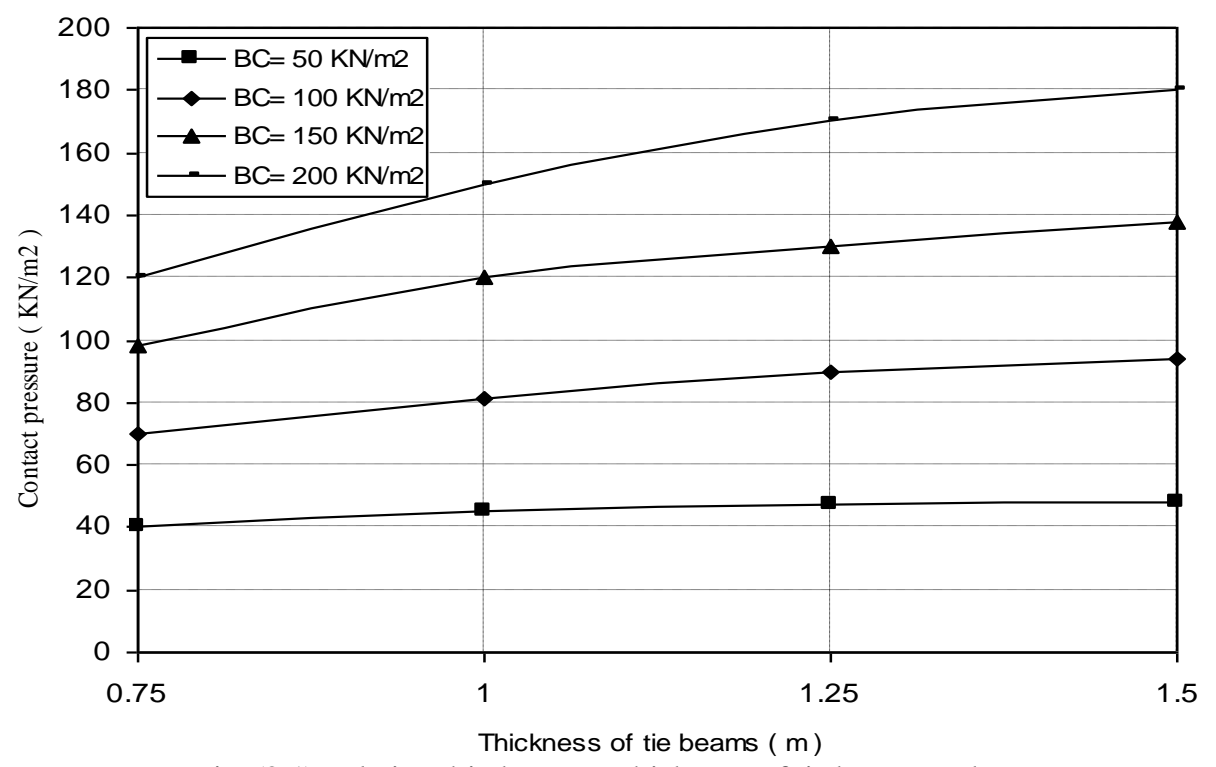

Fig. (2-1) Relationship between thickness of tie beams and contact pressure at middle of strab beam (B1). 


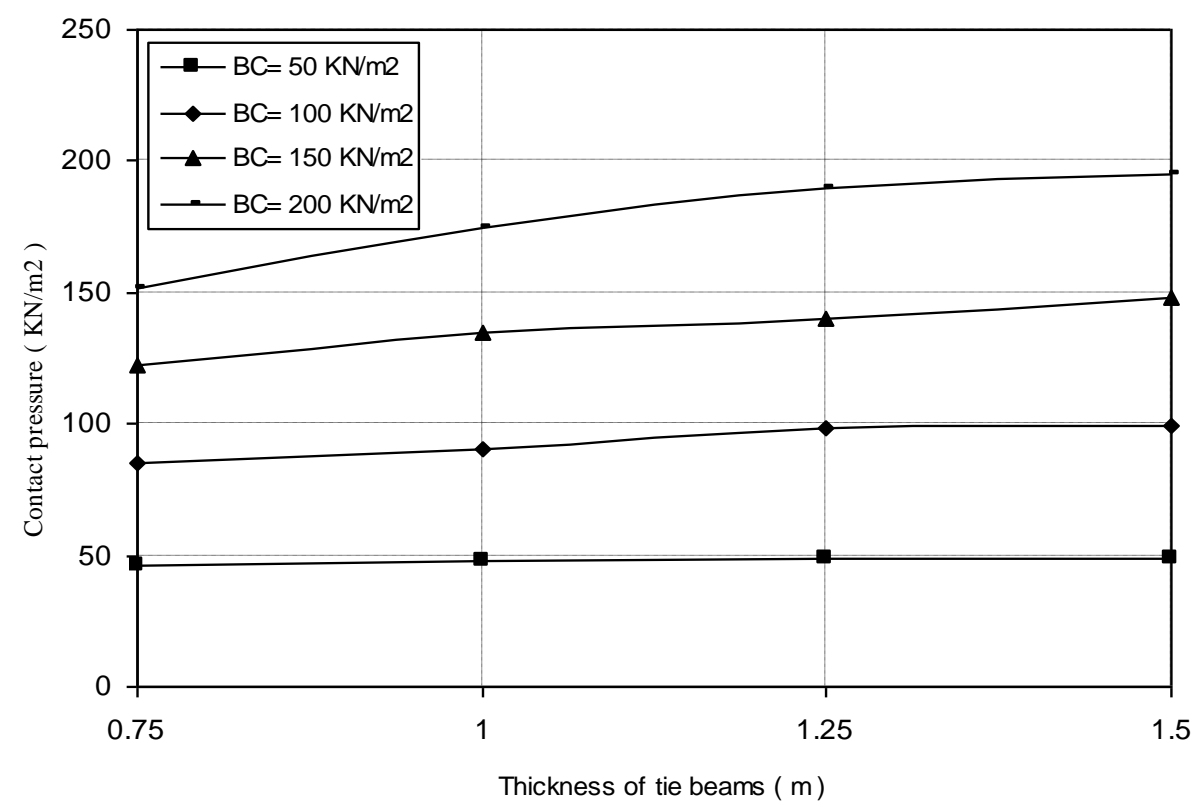

Fig. (2-2) Relationship between thickness of tie beams and contact pressure at center of interior footing (F2).

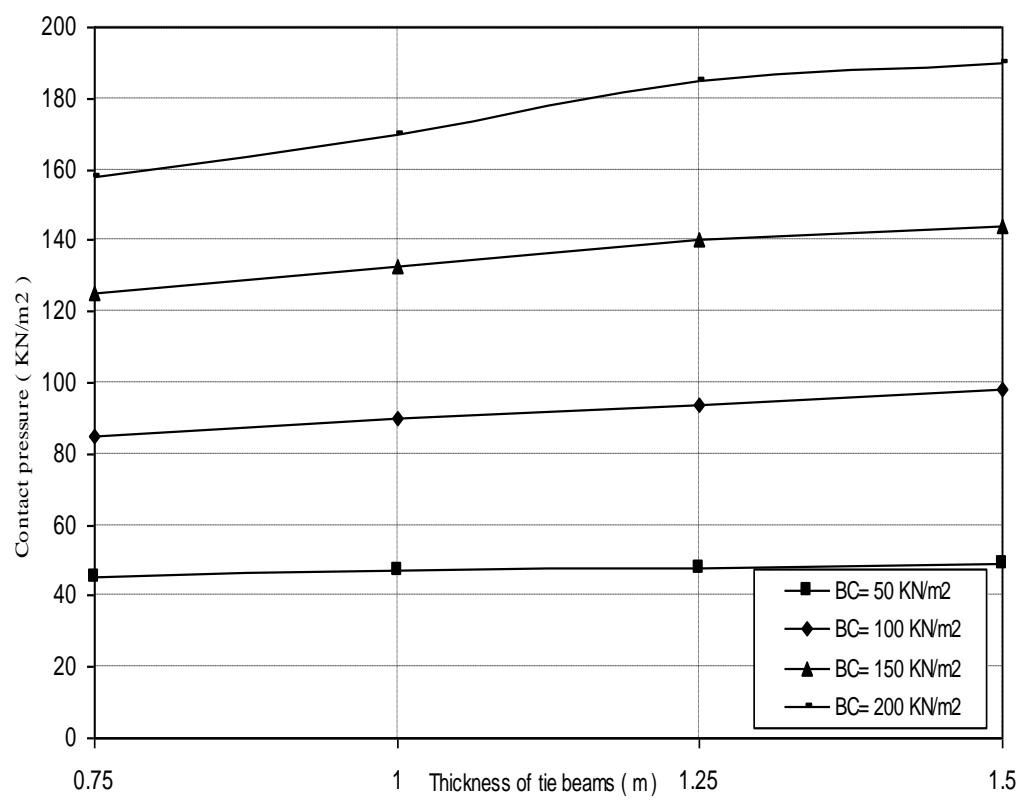

Fig. (2-3) Relationship between thickness of tie beams and contact pressure at middle of tie beam (B2). 


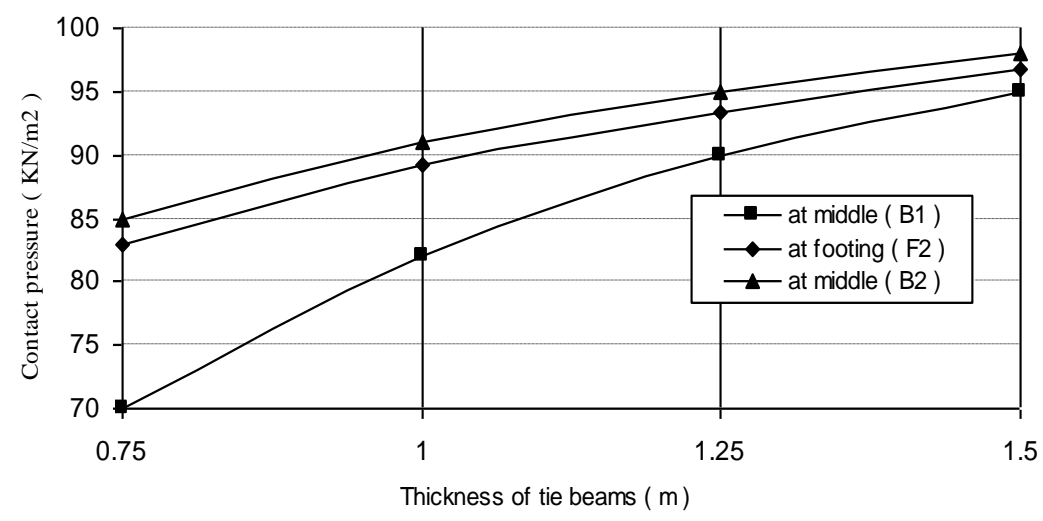

Fig. (3) Relationship between thickness of tie beams and contact pressure at different points at bearing capacity ( $100 \mathrm{KN} / \mathrm{m} 2$ ) .

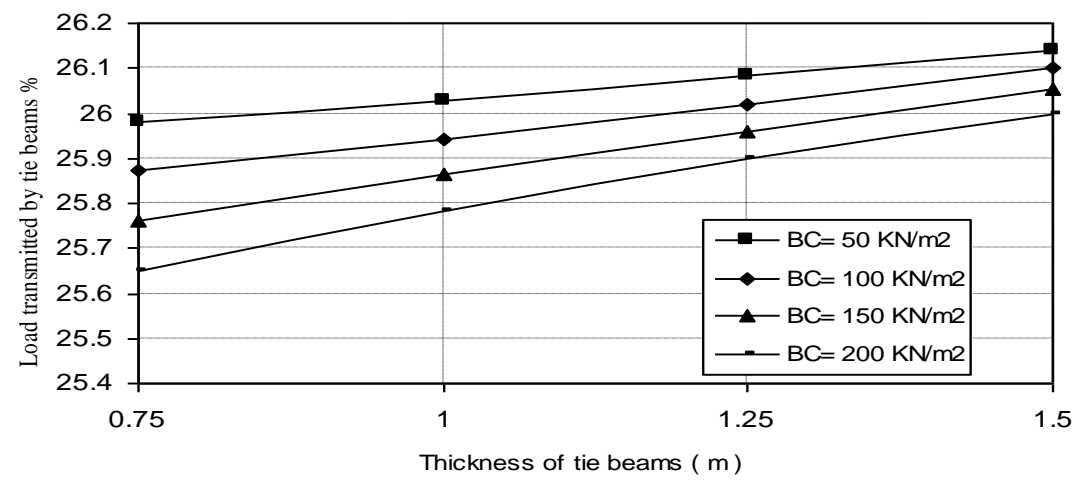

Fig. (4) Effect of tie beams thickness on the percentage of column loads transmitted by tie beams .

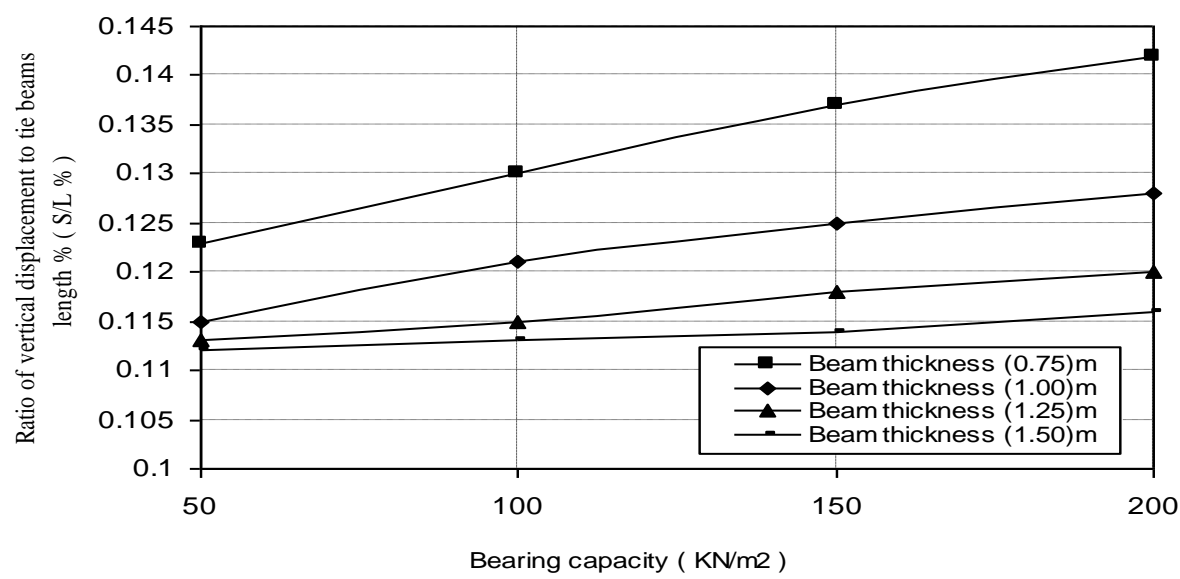

Fig. (5-1) Effect of bearing capacity and thickness of tie beams on the percentage ratio of vertical displacement to length of tie beams at edge of eccentric footing. 


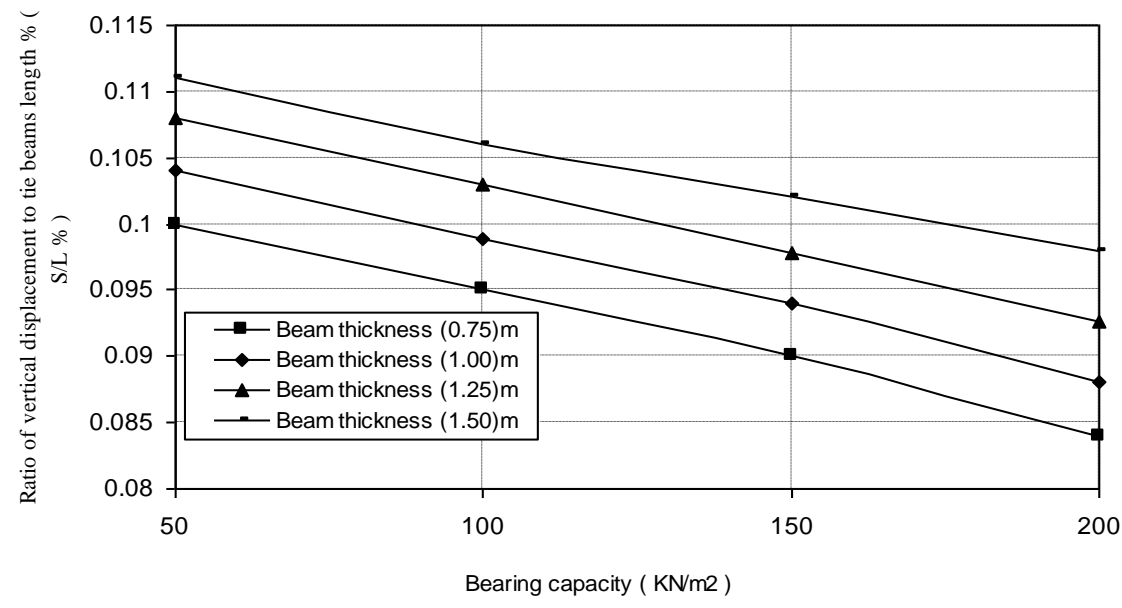

Fig. (5-2) Effect of thickness of tie beams on the percentage ratio of vertical displacement to length of tie beam at middle of strab beams (B1).

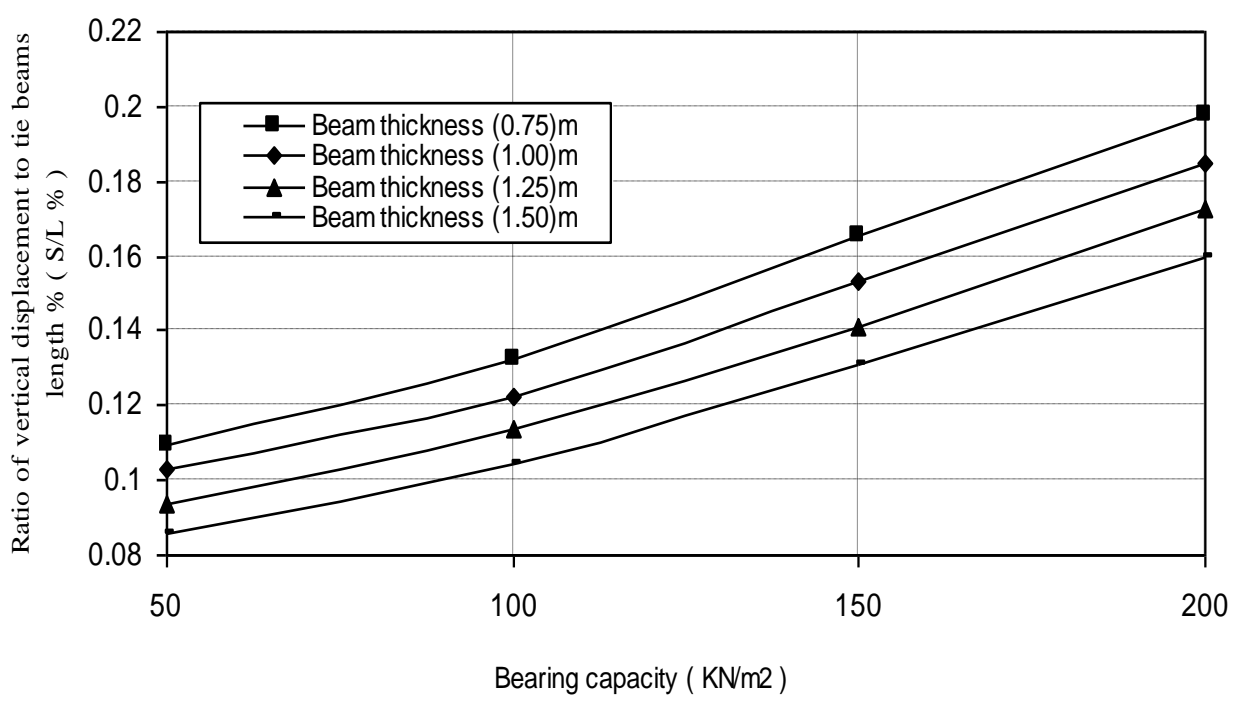

Fig. (5-3) Effect of tie beams thickness on the percentage ratio of vertical displacement to length of tie beams at interior footing ( F2) .

The effect of strap beam thickness on the percentage ratio of maximum differential displacement to length of strap beam $(\Delta \mathrm{S} / \mathrm{L} \%)$ at different values of bearing capacity is shown in Fig.(6). It is clear that the rate of increasing of $(\Delta \mathrm{S} / \mathrm{L} \%)$ with increasing the bearing capacity of soil decreases with increasing the thickness of strap beams. 


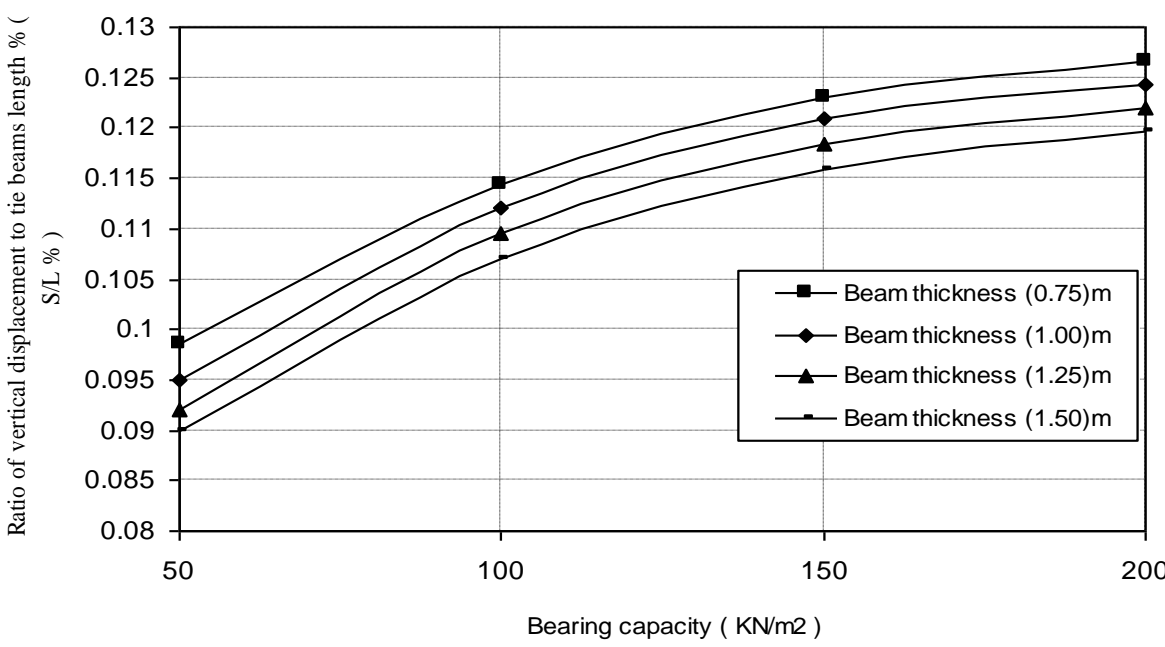

Fig. (5-4) Effect of tie beams thickness on the percentage ratio of vertical displacement to tie beam length at middle of tie beam (B2 ).

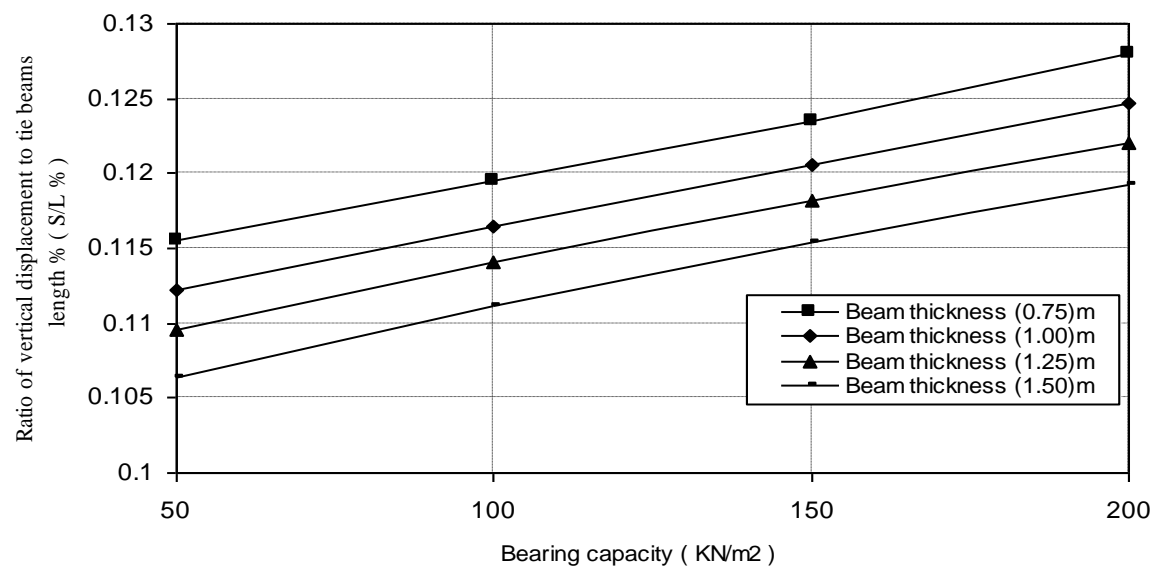

Fig. (5-5) Effect of tie beams thickness on the percentage ratio of vertical displacement to length of tie beams at footing F3 .

Effect of tie beam position on the percentage of column loads transmitted by tie beams is shown in Fig. (7). It can be concluded, that in the case of bearing capacity under the tie beams above the surface of footing is less than that under footings, the percentage of column loads transmitted by tie beams in the same level of footings are bigger than that above the surface of footings. 


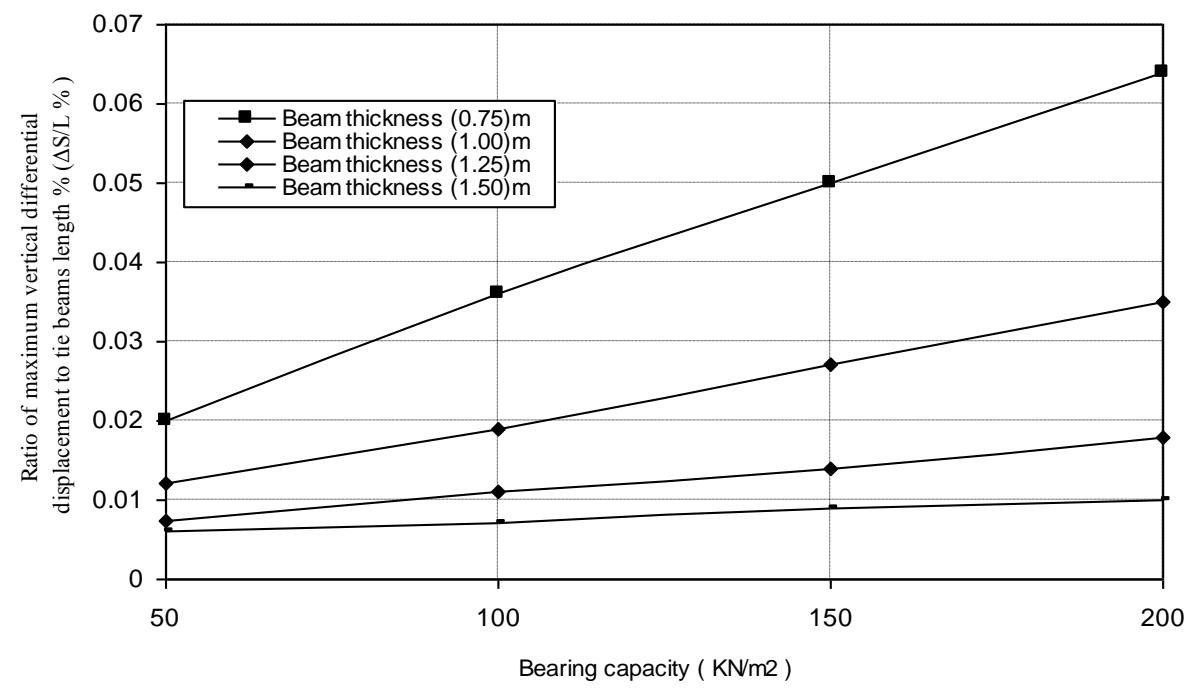

Fig. (6) Effect of strab beams thickness on the percentage ratio of maximum vertical differential displacement to length of strab beams .

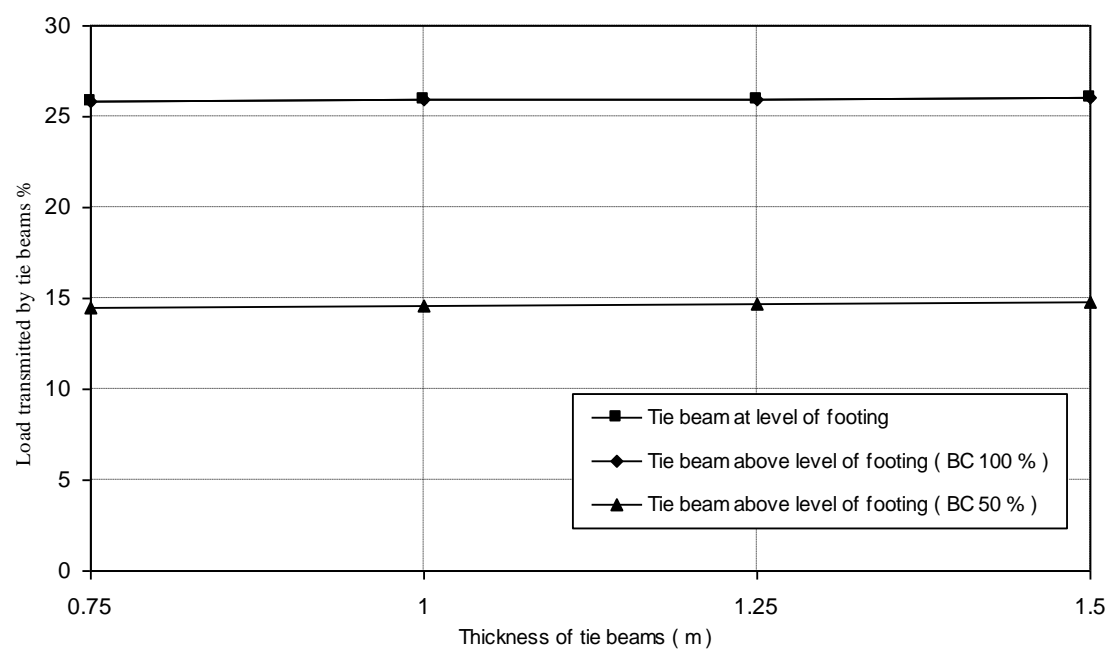

Fig. (7) Effect of tie beam positions on the percentage of load transmitted by tie beams .

The effect of tie position on the percentage ratio of vertical displacement to length of tie beam (S/L\%) at the edge of eccentric footing (F1) at bearing capacity of soil $100 \mathrm{KN} / \mathrm{m}^{2}$ is shown in Fig.(8). Referring to this figure it is noticed that (S/L\%) for strap beam in the same level of footing is less than that above the surface of footing. Also, it can be noticed that for strap beam constructed above the surface of footing, the compaction of soil filling under the strap beam has great effect in the values of load transmitted by tie beams and the vertical displacement of eccentric footings. 


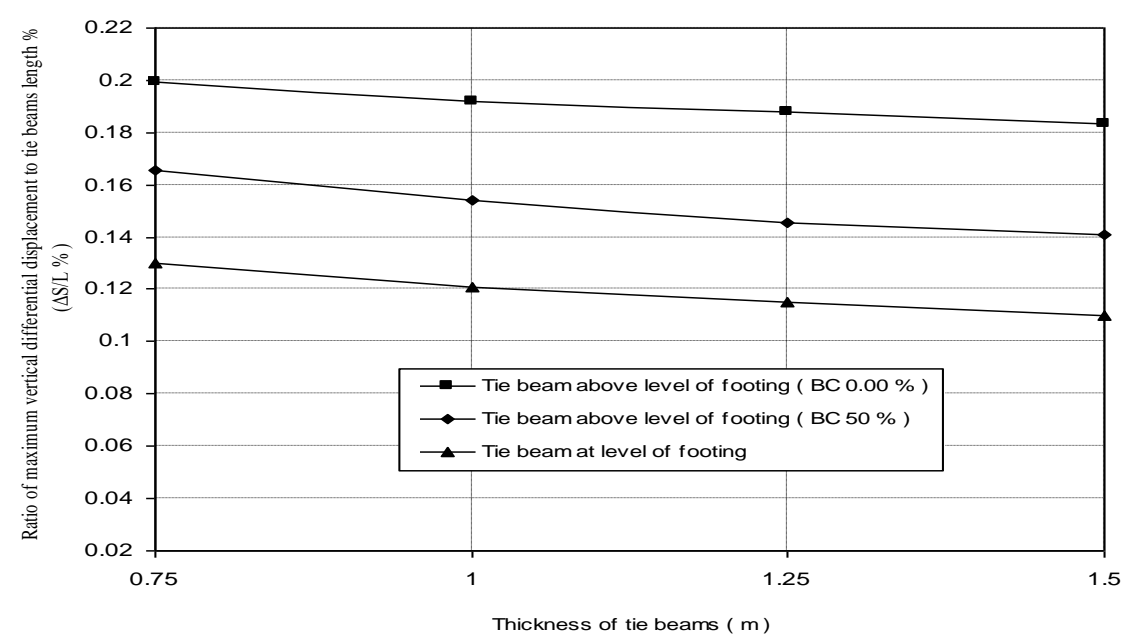

Fig. (8) Effect of tie beam positions on the percentage ratio of vertical dis placement to tie beam length at edge of eccentric footing ( $F 1$ ) at $\mathrm{BC}=100 \mathrm{KN} / \mathrm{m} 2$

\section{CONCLUSIONS}

Based on the numerical study by finite element method on the eccentric footings connected with strap beams and centric footings connected with tie beams considered system, the following conclusion can be drawn:

- The contact pressure under strap beams increases with increasing its rigidity.

- The contact pressure in strap beams should be taken in the design of eccentric footings.

- The percentage of column loads transmitted by strap and tie beams increases as the thickness of strap and tie beams increase.

- Strap and tie beams connected with footings in the same level are transmitted the column loads more than that above the surface of footings.

- Strap and tie beams in the same level of footings are minimized the vertical displacement of footing than that above the surface of footing.

- The footing connected with strap and tie beams can be considered as one entity, so, the column loads may be distributed in footings and tie beams. The actual distributed load must be taken to design the footings and tie beams.

- The height rigidity of strap beams control rotation of eccentric footings.

\section{REFERENCES}

1- Abdel-Shafy, A. G. and Soghair, H.M. (1989), "Strap Beam Analysis Engineering", Research Bulletin, Faculty of Eng. \& Tech.Mataria, Cairo, Egypt, Vol.2.

2- $\quad$ Bazaraa, A. S., Shageen, H.H., Sabry, A. F. and Abd El-Krem, A. H.(1991). "Analysis of Tie-Beam Connected Isolated Footing Resting on Soil". proc. $4^{\text {th }}$ Arab Structural Engineering Conf., , Cairo, Egypt, pp.(1-62)-(1-76). 
3- Bowels, J. E. (1988) "Foundation Analysis and Design" Mc graw-H, New York.

4- COSMOS/M V.2.6 Structural Analysis Finite Element Program.

5- El-Kasaby, E. A. A. (1993) "Behavior of Strap Footing with Tie Beams Resting on Soil”. Civil Engineering Research Magazine (CERM), Al-Azhar University, Vol.15 No.6, pp. 47-59.

6- Elsaadany, M. M. (2004) "Role of Tie -Beam in Isolated Eccentric Shallow Footings". Civil Engineering Research Magazine (CERM), Al-Azhar University, Vol.26, No.1, pp.606-618.

7- El-Shafee, O.M. (1990) "Columns Load Distribution in Two Dimension Shallow Footings-Semelles System". Proc. $1^{\text {st }}$ Alexandria Conf. Structural and Geotechnical Eng., pp.131-139.

8- Glassman, A. (1989); "Behavior of Crossed Beams on Elastic Foundation", ASCE. , Vol. 98, No.SM1, pp.1-11.

9- Kotb, M. (2003) "Effect of Ground Tie-Beams on Stresses in Isolated Footings Resting on Elastic Soil”. Civil Engineering Research Magazine (CERM), A1Azhar University, Vol.25, No.1, pp.173-187.

10- Omer, A. O., (1988) , "Effect of Rigidity of Superstructure on Contact Pressure". Thesis Submitted for M. Sc Degree, Ain Shams University Faculty of Eng., Cairo, Egypt.

\section{"تأثير الكمرات الرابطة على نظام القواعد المنفصلة اللامركزية"}

الكمرات الرابطـة للأساسـات نستخدم بكثرة لربط جميع أنواع القواعد المنفصلة ومنهـا القواعد الغير مركزية ( قواعد الجار ) في حالة قواعد الجار تسمي الكمرات الرابطة لها بالثدادات ـ في هذا البحث ثم دراسـة نظـام الأساسـات المربوطـة بكمرات رابطـة و شـدادات باسـتخدام طريقـة التحليـل الهندسـي للعناصر المحددة ـ ثم دراسة تأثير الكمرات الرابطة للقواعد المنفصلة وكذلك الثدادات الرابطة لقواعد الجار علي ضغط التنامس ونسبة حمل العمود المنتقلة خـلال الكمرات الرابطة و الثـدادات ,النسبة المئوية للإزاحة الرأسية علي طول الكمرات الرابطة عند نقط مختلفة أسفل القواعد و الكمرات الرابطة

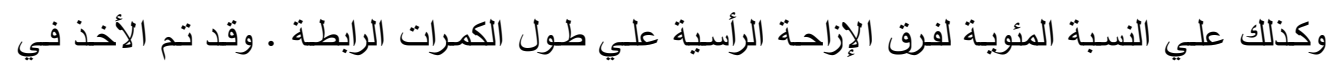
الاعتبار لهذه الدراسة تأثير جساءة الكمرات الرابطة و قدرة تحميل التربة و مواضع الكمرات الرابطة ) مع منسوب القواعد أو أعلاها ) . 